\title{
BASIC CRITERIA AND INDICATORS OF VOCATIONAL TRAINING OF STUDENTS ON THE BASIS OF BIOLOGICAL EDUCATION
}

\section{Karimova N.A.}

Tashkent State Pedagogical University Named After Nizami, Uzbekistan

\section{ABSTRACT}

This article is achieved through active targeted work with school students, identifying their real interests and abilities in the biological sciences, personal preferences, as well as building confidence in choosing the right profession that meets the needs of the city, district, village where they live. Therefore, from a pedagogical point of view, the effectiveness of career choice based on biology education means measuring a person's career choice in accordance with the teacher's recommendations

KEYWORDS: - School, student, career choice, education and upbringing, nature, ecology, environment, animal, plant, career guidance, ability, profession.

\section{INTRODUCTION}

The subjects taught in school play an important role in guiding students to consciously choose a profession. In the process of education and upbringing, two main tasks are performed: the development of professional motivation based on the formation of sustainable interests in academic subjects; second, to improve appropriate mental abilities. Biology, as a subject, has a deep scientific potential, which allows to direct students to various professional activities: agriculture, medicine, ecology, biomedical industry, biological cybernetics, biophysics and other fields.

When organizing the learning process in school, the science teacher should pay special attention to career orientation. In addition, each activity has its own characteristics in each science. To form the desire to work with natural objects, we consider the technology of organizational and pedagogical activities in the field of "Biology".

This technology is characterized by:

- adherence to the principle of nature conservation in teaching and educating students (nature as a habitat; nature in terms of the concept of the nosphere, bioenergy; nature of the individual, his health, activity as a species, etc.);

- In the field of nature protection and environmental education, focus on the restoration of spirituality; 
CURRENT RESEARCH JOURNAL OF PEDAGOGICS 2(12): 39-43, December

2021 DOI: https://doi.org/10.37547/pedagogics-crjp-02-12-09

ISSN 2767-3278

(C)2021 Master Journals

Crossref doi) 81 Google

Accepted 10 $10^{\text {th }}$ December, 2021 \& Published $15^{\text {th }}$ December, 2021

- Analysis of the potential of each branch of biology in the formation of interest in nature and the universe;

- knowledge of natural objects, all living beings in practical activities, education in the spirit of love through compassion;

- formation of a positive attitude to nature, agricultural labor as an attractive, high moral and economic income (especially in market conditions);

- to analyze the level of development of professionally important qualities necessary for successful work in nature among schoolchildren who prefer the biological field.

[] Many professionals work in partnership with nature.

[] These include: occupations related to the cultivation of plants and plants, animals and livestock, forestry, the human body, cells, microorganisms, and the environment. Although biology has its own characteristics as a science, it is possible to organize the following:

- vocational training in the study of theoretical material in biology,

- broaden the understanding of professions related to biology during laboratory classes, practical assignments, problem solving;

- Writing essays, reports and lectures on occupations and production,

- organization of study tours to enterprises, institutions, etc.

- Let's take a closer look at the work that will be done in the classroom.

Thus, the results of our analysis of career opportunities in general secondary schools in the course "Biology" showed that this subject has great professional potential. According to Ya.Klimov's classification, it includes more than
60 professions and specialties related to the type of "man-nature". A. Klimov notes that, in addition to medical professions (mixed type: "human-nature", "human-human"), they can be conditionally divided into 4 segments:

- cytological segment (biochemist, biophysicist, histologist, cytologist, physiologist, biomechanic, etc.);

- genetic segment (biotechnologist, embryologist, breeder, genetic engineer, geneticist, bioethics, gerontologist, microbiologist, etc.);

- evolutionary segment (paleontologist, archeologist, anthropologist, zoologist, botanist, systematist, virologist, algologist, mycologist, entomologist, ichthyologist, hydrobiologist, etc.);

- ecological segment (radiobiologist, ecologist, etiologist, phytocenologist, zoocenologist, agronomist, etc.).

Professional information about these professions is included in the sections of the general biology course. Thus, in the section "Cell as a biological system" the meaning of the professional activity of a cytologist, in the section "Organism as a biological system" - embryologist, histologist, biochemist, biophysical activity, in the section "Heredity and variability - the characteristics of the organism" information on decision-making activities. In the 11th grade "Biology" course: "The evolution of species", "Origin and evolution of life on Earth", "Human economic activity" focuses on the nature of the professional activity of paleontologist, systematic, evolutionist, medical-ecologist, breeder, engineer-geneticist. In extracurricular activities in biology, we will focus on the content of vocational guidance of students. General secondary schools ensure the acquisition of (universal and special) competencies as a result of the implementation of the content of the vocational training program 
CURRENT RESEARCH JOURNAL OF PEDAGOGICS 2(12): 39-43, December

2021 DOI: https://doi.org/10.37547/pedagogics-crjp-02-12-09

ISSN 2767-3278

(C)2021 Master Journals

Crossref do: 81 Google

Accepted 10 $10^{\text {th }}$ December, 2021 \& Published $15^{\text {th }}$ December, 2021

in extracurricular activities; allowing students to study the design of individual educational programs and choose the next vocational education program and the knowledge to implement it: communicative competence; ability to self-evaluate; to monitor their successes and shortcomings, to develop individual educational programs and eliminate them in accordance with the tasks set out in it; selection and analysis of data from open information resources (including the Internet), etc. is achieved through. Career orientation of students in biology in extracurricular activities can be carried out through scientific and social projects, experiments, internships (industrial and social), excursions, clubs, classes in clubs and more.

In order to more effectively manage the professional development of students at school, career guidance should be divided into two stages:

Phase I (grades 5-7) helps to shape students' interests, abilities, and social values related to their career choices and their place in society. At the same time, future professional activity at this stage serves as a way to create a certain lifestyle, to realize their potential.

Phase II (grades 8-9) helps to form ideas about professional skills, prospects for professional growth and production, the rules of career choice, the ability to properly assess their personal capabilities in accordance with the requirements of the chosen profession. When choosing a career, the main focus is on counseling support, which determines the action strategy to take over the reserve option.

One of the most important issues in the management of career guidance is to determine the criteria for career guidance and performance indicators. Currently, the effectiveness of career guidance in schools is often determined by the number (in percent) of students who choose career-oriented careers. If this is the main goal of career guidance, without serious diagnostic and parenting work with students, then all work will go in a specific direction that hinders career guidance itself and reduces the confidence of students and their parents in it.

This goal is achieved through active targeted work with schoolchildren, identifying their real interests and abilities in the biological sciences, personal preferences, as well as building confidence in choosing the right profession that meets the needs of the city, district, village where they live. Therefore, from a pedagogical point of view, the effectiveness of career choice based on biology education means measuring a person's career choice in accordance with the teacher's recommendations. However, pedagogical recommendations are assumed to be based on consideration of both personal and social needs. Accordingly, the more students choose the professions recommended by them, the higher the career-orienting effectiveness of teachers and schools.

The main criteria and indicators of the effectiveness of vocational guidance on the basis of biological education, first of all:

1. Adequate information about the profession and ways to acquire it. Without a clear idea of the content and working conditions of the chosen profession, the student will not be able to make a reasonable choice. An indicator of the sufficiency of information is to clearly present to this person the demand for the profession, the exact place of its acquisition, the needs of society for these professionals.

2. The need to make a reasonable choice of profession. Indicators of the need for a profession-based professional choice are the student's self-activity in obtaining the necessary information about a particular profession, the desire to test himself in certain areas of activity (not necessarily to be done, but manifested). 
CURRENT RESEARCH JOURNAL OF PEDAGOGICS 2(12): 39-43, December

2021 DOI: https://doi.org/10.37547/pedagogics-crjp-02-12-09

ISSN 2767-3278

(C)2021 Master Journals

Crossref do: 81 Google

Accepted 10 $10^{\text {th }}$ December, 2021 \& Published $15^{\text {th }}$ December, 2021

3. The student's belief in the social significance of labor, i.e., their vital value, is directly related to the need to choose a profession. The attitude of 8th-9th graders to work is in line with the need to choose a reasonable career as a vital value.

4. The level of self-knowledge of the student. The validity of a student's choice will largely depend on a deeper study of his or her professionally important qualities. It should be borne in mind that only a qualified professional can provide a student with sufficient and complete information about his or her professionally important qualities.

5. Students have a sound career plan. The validity of a career choice is, rightly, one of the necessary criteria for career guidance. The specific individual characteristics of a person in the field of knowledge in accordance with the requirements of career choice are indicators of the validity of important professional qualities that directly affect the success of professional activity.

- The following are the process criteria for the effectiveness of work on vocational guidance of students on the basis of biological sciences:

- The individual nature of the impact of referral to any profession, such as biologist, nurse, gardener, botanist, geneticist, breeder, medical laboratory assistant, zoologist, veterinarian (taking into account the individual characteristics of the student, the nature of family relationships, work experience, professional development) taking);

- The direction of the impact of career guidance, primarily affects the overall development of the individual (ensuring freedom in choosing a profession, creating opportunities for competition in various fields of professional activity, stimulating activity in independent choice of professional field and setting a professional plan).
With the help of career guidance activities (role, didactic games, conversations, competitions, socially useful work, excursions to industrial enterprises, national holidays, etc.) the perception of the world of professions is expanded, conscientious attitude to work, understanding its role in human life and society, career choice, develops interest in the future profession.

Thus, the design of a meaningful part of the curriculum for vocational training of students based on the content of biology education is the essence of the basic biology curriculum (by class) in terms of the specific content of disciplines, as well as the specificity of content, research and design work. is a collective creative result of the methodological work of the teaching staff, depending on the results of the formation of universal learning activities (UOF) and ICT competencies.

\section{REFERENCES}

1. Неъматов Ш.Э. ва бошқ. Ўқувчиларни касб-хунарга йўналтириш орқали умумий ўрта ва ўрта махсус, касб-хунар таълими узвийлигини таъминлашнинг назарий методологик асослари. Тошкент: ЎзПФИТИ босмахонаси, 2015. - 152 бет.

2. Нешенкова Т.Д. Современные подходы к профориентации // https://infourok.ru/sovremenniepodhodi-k-proforientacii-3616046.html

3. Толипова Ж.О., А.Т.Ғофуров. Биология ўқитиш методикаси. - Т.: 2012 . - 128 б.

4. Климов Е.А. Психология 
CURRENT RESEARCH JOURNAL OF PEDAGOGICS 2(12): 39-43, December

2021 DOI: https://doi.org/10.37547/pedagogics-crjp-02-12-09

ISSN 2767-3278

(C)2021 Master Journals

Crossref dof 81 Google

Accepted 10 ${ }^{\text {th }}$ December, $2021 \&$ Published 15 th December, 2021

профессионального самоопределения:

учеб. пособие для студентов вузов,

обучающихся по специальностям:

Педагогика и психология, Соц.

педагогика, Педагогика. - М.: Academia,

2004. -301 c. 